\title{
Synthesis and Characterization of New 10- and 12-
}

\section{vertex CO-ligated Metallathiaboranes}

Susana Luaces, ${ }^{\dagger}$ Jonathan Bould, ${ }^{*}+,+$ Ramón Macias, ${ }^{*}{ }^{\dagger}$ Rodrigo Sancho, ${ }^{\dagger}$ Pilar García-Orduña, ${ }^{\dagger}$ Fernando J. Lahoz ${ }^{\dagger}$ and Luis A. Oro ${ }^{\dagger}$

${ }^{\dagger}$ Instituto de Síntesis Química y Catálisis Homogénea (ISQCH), Universidad de Zaragoza-Consejo Superior de Investigaciones Científicas, 50009-Zaragoza, Spain. ${ }^{t}$ Institute of Inorganic Chemistry of the Academy of Sciences of the Czech Republic, 25068 Husinec- ̌̌ež 1001, Czech Republic

rmacias@unizar.es

RECEIVED DATE (to be automatically inserted after your manuscript is accepted if required according to the journal that you are submitting your paper to)

Dedicated to Professor Thomas P. Fehlner on his $75^{\text {th }}$ birthday. He has been a superb mentor of many scientists around the world working on "inorganometallic chemistry". 


\section{Graphical abstract: synopsis}

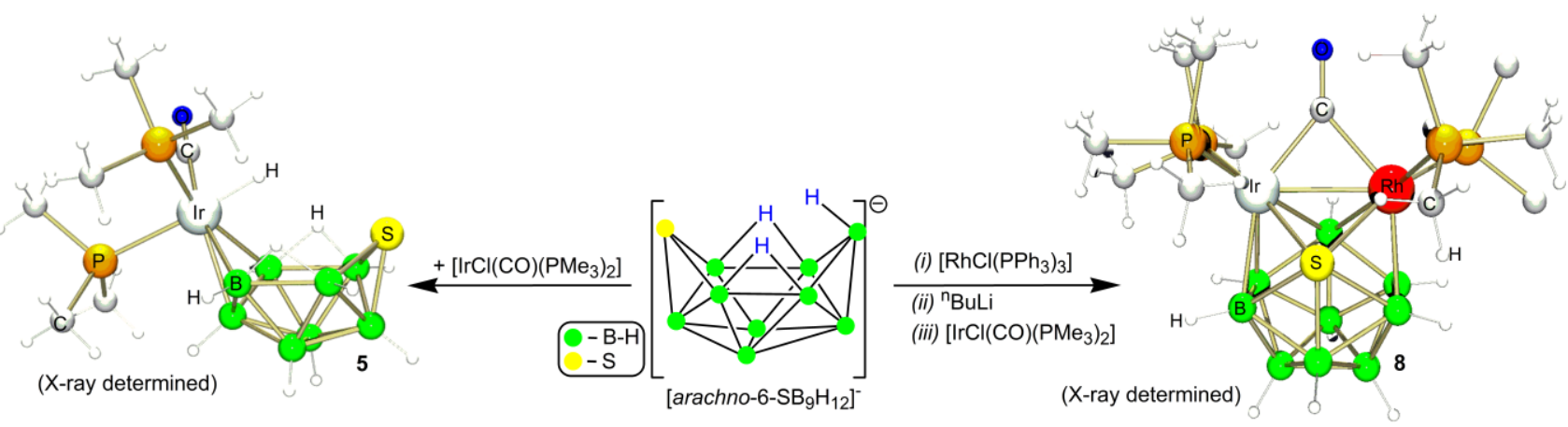

Reactions of carbonyl complexes of rhodium and iridium with 9- and 10-vertex thiaboranes, and an 11-vertex rhodathiaborane are presented. Reactions produce new metallathiadecaboranes and a 12vertex iridarhodathiaborane. 


\section{ABSTRACT}

The reaction between $\left[\text { arachno-6- } \mathrm{SB}_{9} \mathrm{H}_{12}\right]^{-}$and $\left[\mathrm{IrCl}(\mathrm{CO})\left(\mathrm{PMe}_{3}\right)_{2}\right]$ affords the previously reported 11-vertex cluster, [8,8,8-(CO)(PMe3)2-arachno-8,7-IrSB9H10] (4), and small amounts of the 10vertex iridathiaborane $\left[9,9,9,9-(\mathrm{CO})(\mathrm{H})\left(\mathrm{PMe}_{3}\right)_{2}\right.$-arachno-9,6- $\left.\mathrm{IrSB}_{8} \mathrm{H}_{10}\right](5)$. Alternatively, a rational synthesis of iridathiadecaboranes is effected from the reaction of the 9-vertex anion [arachno-4$\left.\mathrm{SB}_{8} \mathrm{H}_{11}\right]^{-}$with $\left[\mathrm{MCl}(\mathrm{CO})\left(\mathrm{PPh}_{3}\right)_{2}\right]$, to afford new CO-ligated 10-vertex metallathiaboranes of formulation, $\left[9,9,9,9-(\mathrm{CO})(\mathrm{H})\left(\mathrm{PPh}_{3}\right)_{2}\right.$-arachno-9,6- $\left.\mathrm{MSB}_{8} \mathrm{H}_{10}\right]$, where $\mathrm{M}=\mathrm{Rh}(\mathbf{6})$ and $\mathrm{Ir}(7)$ in useful yields of $61 \%$ and $60 \%$ respectively. Treatment of the 11 -vertex rhodathiaborane, $\left[8,8-\left(\mathrm{PPh}_{3}\right)_{2}-8,7-\right.$ nido- $\left.\mathrm{RhSB}_{9} \mathrm{H}_{10}\right](\mathbf{1})$ with $n \mathrm{BuLi}$, followed by addition of $\left[\mathrm{IrCl}(\mathrm{CO})\left(\mathrm{PMe}_{3}\right)_{2}\right]$ affords the 12 -vertex iridarhodathiaborane, [1,2-( $\mu$-CO)-1,1,2-( $\left(\mathrm{PMe}_{3}\right)_{3}-2-\left(\mathrm{PPh}_{3}\right)-$ closo-1,2- $\left.\mathrm{IrRhSB}_{9} \mathrm{H}_{9}\right](\mathbf{8})$ in low yield (0.7\%). The 10-vertex metallathiaboranes, $\mathbf{5 ,} \mathbf{6}$ and 7, and the bimetallic 12-vertex cluster, 8 , have been characterized by multinuclear NMR spectroscopy. In addition, the molecular structures of compounds 5, 6, and 8 have been studied by X-ray diffraction.

\section{KEYWORDS}

Boron; Thiaborane; Metallathiaborane, Metallaborane; Carbonyl; Cluster

\section{Introduction}

The higher binary boron hydrides form polyhedral cluster structures containing only boron and hydrogen atoms. The boron centres in the cluster framework may be replaced by other elements of the Periodic Table such as the $p$-block elements carbon, nitrogen and sulphur to afford heteroboranes, or, in addition, transition metals to give metallaborane or metallaheteroborane compounds. Amongst the heteroboranes, the most extensively studied are the carboranes and their metallacarboranes [1-16], but, by comparison, the chemistry of other main-group polyhedral heteroand metallaheteroboranes is quite limited with some of the more studies being the thiaboranes [1726]. The development of convenient synthetic routes to thiaborane clusters has aided this; for example, Scheme 1 illustrates the synthesis of the 10-vertex thiaborane anion, [arachno-6- $\left.\mathrm{SB}_{9} \mathrm{H}_{12}\right]^{-}$ and the 9-vertex thiaborane, arachno-4-SB ${ }_{8} \mathrm{H}_{12}[27,28]$. 
Scheme 1 Synthesis of thiaborane starting materials, used in this work

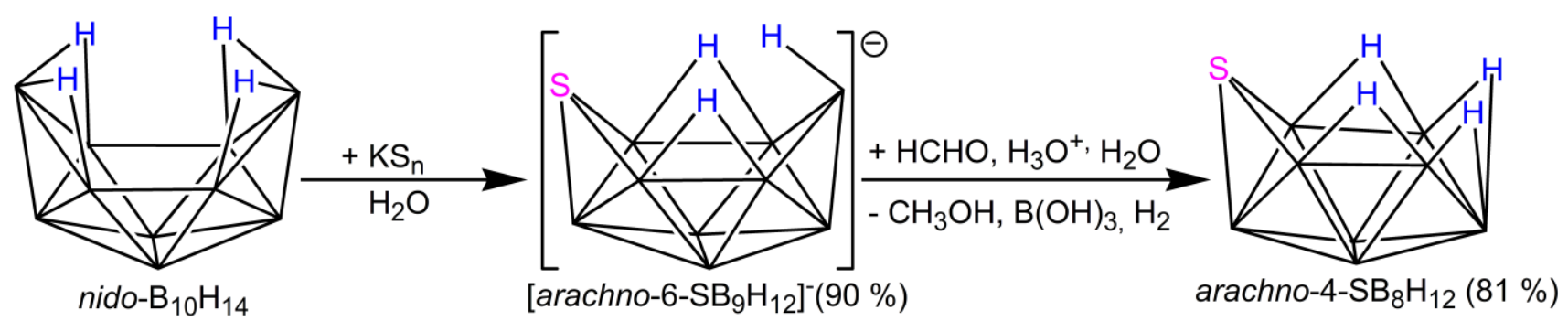

In recent years, we have been developing the organometallic chemistry of the 11-vertex rhodathiaborane $\left[8,8-\left(\mathrm{PPh}_{3}\right)_{2}\right.$-nido-8,7- $\left.\mathrm{RhSB}_{9} \mathrm{H}_{10}\right](\mathbf{1})$, prepared from $\left[\mathrm{RhCl}\left(\mathrm{PPh}_{3}\right)_{3}\right]$ and readily available $\mathrm{Cs}\left[\right.$ arachno-6-SB $\left.{ }_{9} \mathrm{H}_{12}\right]$, and its pyridine-ligated derivative $\left[8,8,8-\left(\mathrm{PPh}_{3}\right)_{2}(\mathrm{H})-9-\left(\mathrm{NC}_{5} \mathrm{H}_{5}\right)-\right.$ nido-8,7- $\mathrm{RhSB}_{9} \mathrm{H}_{9}$ ] (2) [29-32]. The latter combines B-H terminal, B-H-B bridging and M-H sites in its structure, which are quite rarely found in metallaboranes and metallaheteroboranes (the majority incorporates B-H terminal, and B-H-B and M-H-B bridging hydrogen atoms), conferring 2 with a rich reactivity. In this regard, 2 undergoes reversible dehydrogenation to give [1,1-( $\left.\mathrm{PPh}_{3}\right)_{2}-3-$ $\left(\mathrm{NC}_{5} \mathrm{H}_{5}\right)$-closo-1,2- $\left.\mathrm{RhSB}_{9} \mathrm{H}_{8}\right]$ (3) and, in conjunction with the reaction of $\mathbf{1}$ with ethylene, it defines a catalytic cycle that operates in the hydrogenation of alkenes [30, 31]. The mode of action on these 11-vertex rhodathiaboranes is reminiscent of non-innocent-ligand containing complexes that act as catalyst promoters [33]. Thus, the $\left\{\eta^{4}-\mathrm{SB}_{9} \mathrm{H}_{9}\left(\mathrm{NC}_{5} \mathrm{H}_{5}\right)\right\}$ and $\left\{\eta^{6}-\mathrm{SB}_{9} \mathrm{H}_{8}\left(\mathrm{NC}_{5} \mathrm{H}_{5}\right)\right\}$ fragments in compounds $\mathbf{2}$ and $\mathbf{3}$, respectively, may be regarded as ligands that directly participate in the reactions, thereby giving to the system a bifunctional acid / base character, as shown by the heterolytic cleavage of $\mathrm{H}_{2}$ and its reactivity with Brønsted acids [30, 34].

Advances in organometallic and inorganometallic reaction chemistry lie [35, 36], in a large part, on the introduction of ligands capable of bestowing a new reactivity on the transition metal centres. Similarly, in metallaheteroboranes, the modification of the coordination sphere around the metal centre, in order to tune its reactivity, may be achieved by a variation of the heteroborane fragment itself. Thus, as part of our interest in the search of new metallathiaborane reaction chemistry, we describe reactions of iridium and rhodium carbonyl complexes with [arachno-4- $\left.\mathrm{SB}_{8} \mathrm{H}_{11}\right]^{-}$, which 
give $\mathrm{H}$ - and CO-ligated 10-vertex clusters that contain a $\left\{\eta^{3}-\mathrm{SB}_{8} \mathrm{H}_{10}\right\}$ fragment. Additionally, we, report here a new 12-vertex rhodium, iridium bimetallic cluster prepared from the rhodathiaborane $\mathbf{1}$.

\section{Results and Discussion}

The caesium thiadecaborane salt, $\mathrm{CsSB}_{9} \mathrm{H}_{12}$, has proven to be a very useful starting material for the synthesis of new metallathiaboranes [26, 37-41]. In particular, [8,8-( $\left.\mathrm{PPh}_{3}\right)_{2}$-nido-8,7- $\left.\mathrm{RhSB}_{9} \mathrm{H}_{10}\right]$ is prepared in high yield (90\%) from the reaction between the $\mathrm{CsSB}_{9} \mathrm{H}_{12}$ and $\left[\mathrm{RhCl}\left(\mathrm{PPh}_{3}\right)_{3}\right][42,43]$. Following a similar approach, we have recently prepared the CO-ligated analogue, [8,8,8$(\mathrm{CO})\left(\mathrm{PMe}_{3}\right)_{2}$-nido-8,7-IrSB $\left.\mathrm{H}_{10}\right](4)$, using $\left[\mathrm{IrCl}(\mathrm{CO})\left(\mathrm{PMe}_{3}\right)_{2}\right]$ as the metal complex in ca $70 \%$ yield [29]. However, further investigation has revealed that the 10-vertex iridathiaborane $[9,9,9,9-$ $(\mathrm{CO})(\mathrm{H})\left(\mathrm{PMe}_{3}\right)_{2}$-arachno-9,6- $\left.\mathrm{IrSB}_{8} \mathrm{H}_{10}\right](5)$, is also formed as a co-product (ca $7 \%$ ) by a boron vertex cluster dismantling process (Scheme 2, A). Methanol has the potential to act as a deboronating agent, such as in the high yield synthesis of $\left[\left(\mathrm{PR}_{3}\right)_{2} \mathrm{MB}_{8} \mathrm{H}_{12}\right]$ from the addition of $\left[\mathrm{MCl}_{2}\left(\mathrm{PR}_{3}\right)_{2}\right]$, where $\mathrm{M}=\mathrm{Pt}$ or $\mathrm{Pd}$, to $\mathrm{KB}_{9} \mathrm{H}_{14}$ in $\mathrm{MeOH}$ at ambient temperature [44]. Thus, if the reaction of the salt $\mathrm{CsSB}_{9} \mathrm{H}_{12}$ with the metal complex is carried out in $\mathrm{MeOH}$ together with $\left[\mathrm{IrCl}(\mathrm{CO})\left(\mathrm{PPh}_{3}\right)_{2}\right]$ instead of $\left[\operatorname{IrCl}(\mathrm{CO})\left(\mathrm{PMe}_{3}\right)_{2}\right]$, an ca $38 \%$ yield of two isomers of $\left[\left(\mathrm{PPh}_{3}\right)_{2} \mathrm{H}(\mathrm{CO})-\right.$ nido- $\left.-\mathrm{IrSB}_{8} \mathrm{H}_{10}\right]$ is obtained. The two isomers are based on different ligand arrangements of the $\left\{\operatorname{Ir}(\mathrm{CO}) \mathrm{H}\left(\mathrm{PPh}_{3}\right)_{2}\right\}$ moiety with respect to the $\left\{\mathrm{SB}_{8} \mathrm{H}_{10}\right\}$ cage, and separation of these very similar species in order to more definitively characterise the isomers was too onerous to achieve. We therefore undertook a direct rational synthesis from the [arachno-4- $\left.\mathrm{SB}_{8} \mathrm{H}_{11}\right]$ anion and $\left[\mathrm{IrCl}(\mathrm{CO})\left(\mathrm{PPh}_{3}\right)_{2}\right]$. The $\left[\right.$ arachno-4-SB $\left.{ }_{8} \mathrm{H}_{12}\right]$ precursor is conveniently prepared from $\mathrm{CsSB}_{9} \mathrm{H}_{12}$ and may be deprotonated with MeLi. Thus deprotonation of the 9-vertex thiaborane, arachno-4- $\mathrm{SB}_{8} \mathrm{H}_{12}$, with MeLi in ether and subsequent addition of $\left[\mathrm{MCl}(\mathrm{CO})\left(\mathrm{PPh}_{3}\right)_{2}\right]$, where $\mathrm{M}=\mathrm{Rh}$ and $\mathrm{Ir}$, afforded the corresponding 10-vertex metallathiaboranes, $\quad\left[9,9,9,9-(\mathrm{CO})(\mathrm{H})\left(\mathrm{PPh}_{3}\right)_{2}\right.$-arachno-9,6- $\left.\mathrm{MSB}_{8} \mathrm{H}_{10}\right]$, where $\mathrm{M}=\mathrm{Rh}(6)$ and Ir (7), in good yields of 60 and 61\% respectively (Scheme 2, B). These reactions can be described as the oxidative addition the $\left[\mathrm{SB}_{8} \mathrm{H}_{11}\right]$ anion to the square planar metal complexes; formally the $\left\{\mathrm{M}(\mathrm{CO})\left(\mathrm{PPh}_{3}\right)_{2}\right\}^{+}$fragment inserts between the $\mathrm{BHB}$ bridging hydrogen 
atom and the $\left\{\mathrm{B}(6) \mathrm{B}(7) \mathrm{B}(8\}\right.$ cluster face with the $\left\{\mathrm{M}(\mathrm{CO})(\mathrm{H})\left(\mathrm{PPh}_{3}\right)_{2}\right\}$ moiety becoming a new vertex.

Scheme 2 Reactions of thiaboranes with square planar M(I) complexes of Rh and Ir

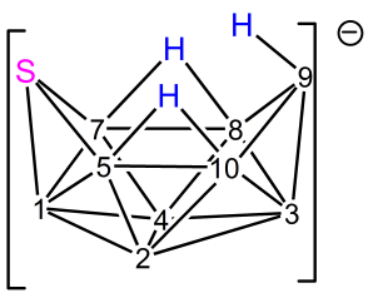

A [arachno-6- $\left.\mathrm{SB}_{9} \mathrm{H}_{12}\right]^{-}$
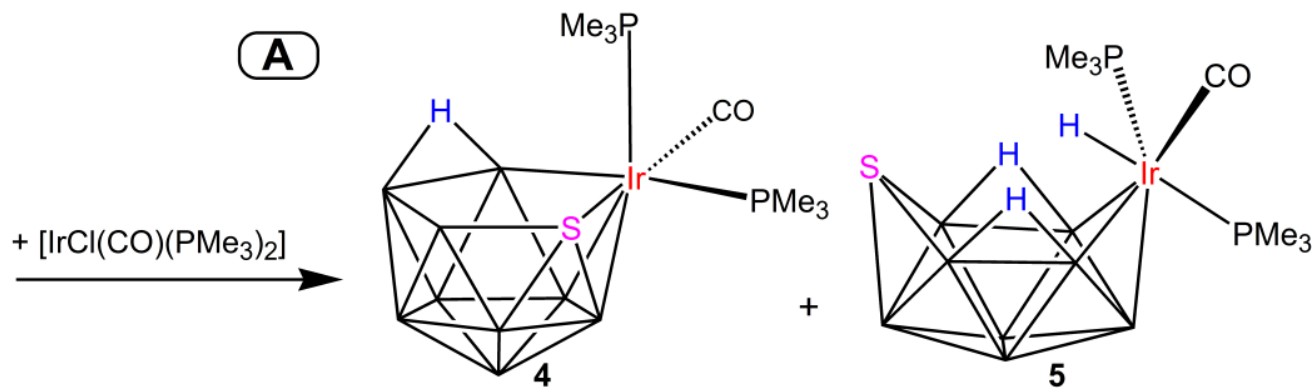

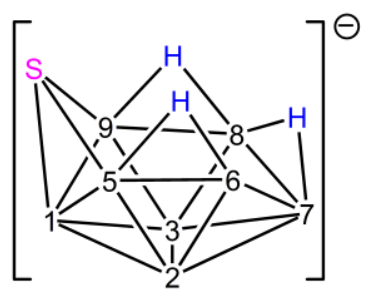

[arachno-4-SB $\mathrm{H}_{11}$ ]
(B)

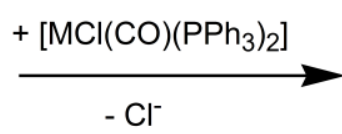

These new CO-ligated metallathiaboranes, $\mathbf{5 , 6}$ and 7, are characterized by multielement NMR and IR spectroscopies, and mass spectrometry. In addition, the molecular structures of $\mathbf{5}$ and $\mathbf{6}$ have been determined by X-ray diffraction analyses (Figure 1). Both clusters exhibit a 10-vertex boat-type structure with the $\left\{\mathrm{M}(\mathrm{H})(\mathrm{CO})\left(\mathrm{PR}_{3}\right)_{2}\right\}$ fragment connected to the $\left\{\eta^{3}-\mathrm{SB}_{8} \mathrm{H}_{10}\right\}$ assembly, as part of the hexagonal $\{\mathrm{M}(9) \mathrm{B}(8) \mathrm{B}(7) \mathrm{S}(6) \mathrm{B}(5) \mathrm{B}(10)\}$ face. Two hydrogen atoms bridge the $\mathrm{B}(7)-\mathrm{B}(8)$ and $\mathrm{B}(5)-\mathrm{B}(10)$ edges. Both metallathiaboranes exhibit the same stereochemistry around the metal centre with a phosphine ligand $[\mathrm{P}(2)$ in Figure 1] trans to the hydride, which occupies an endo-position over the open face and the carbonyl and the second phosphine, $\mathrm{P}(1)$, occupy exo-polyhedral positions trans to the $\mathrm{B}(8)$ and $\mathrm{B}(10)$ vertices, respectively. The M-P bonds are shorter for the iridium cluster as expected from the better $\sigma$-donor capabilities of $\mathrm{PMe}_{3}$ vs. $\mathrm{PPh}_{3}$. The $\mathrm{Rh}(9)-\mathrm{P}(2)$ and $\operatorname{Ir}(9)-\mathrm{P}(2)$ 
bonds are $0.0888(5)$ and $0.0469(16) \AA$ longer than the $\mathrm{M}(9)-\mathrm{P}(1)$ bonds, reflecting the strong trans influence of the hydride ligand.

The structures of $\mathbf{5}$ and $\mathbf{6}$ resemble other crystallographically determined arachnometalladecaboranes such as $\left[6,6,6,6-(\mathrm{PMe} 2 \mathrm{Ph})_{2}(\mathrm{CO})(\mathrm{H})-9-\mathrm{PPh}_{3}-\mathrm{IrB}_{9} \mathrm{H}_{11}\right]$ and $[6,6-(\mathrm{Cp} *)(\mathrm{CNEt})-9-$ (CNEt)- $\left.\mathrm{RhB}_{9} \mathrm{H}_{11}\right][45,46]$. The molecular frameworks of all these compounds are formally derived from an icosahedron by the removal of two vertices, with the structures corresponding to that expected for a 13 skeletal-electron-pair (sep) arachno-cluster with 10 vertices. Interestingly, the metallaboranes [6,6-( $\left.\mathrm{PMe} 2 \mathrm{Ph})_{2}-9-\left(\mathrm{PMe}_{2} \mathrm{Ph}\right)-\mathrm{MB}_{9} \mathrm{H}_{11}\right]$, where $\mathrm{M}=\mathrm{Pt}$ or $\mathrm{Pd}[47,48]$, and platinathiaboranes [8-OEt-9,9-( $\left.\left.\mathrm{PPh}_{3}\right)_{2}-9,6-\mathrm{PtSB}_{8} \mathrm{H}_{10}\right]$ and [9,9- $\left.\left(\mathrm{PPh}_{3}\right)_{2}-9,6-\mathrm{PtSB}_{8} \mathrm{H}_{10}\right]$ [49], have 12 sep's that correspond to 10-vertex nido-structures. Formally, the 10-vertex boat-type cage is obtained by the removal of the vertex of connectivity six of an octadodecahedron and, therefore, the WilliamsWade cluster geometry and electron-counting approach predicts the same 10-vertex cluster geometry for frameworks with 12 or 13 sep's $[50,51]$. However, the presence of bridging hydrogen atoms flanking $\mathrm{B}(5) \mathrm{B}(10)$ and $\mathrm{B}(7) \mathrm{B}(8)$ positions on the open face is typical of ten-vertex arachnopolyhedral boron-containing compounds [52-55]. And it has been recognized that metallaheteroboranes that incorporate $\left\{\mathrm{ML}_{2}\right\}$-metal fragments, where $\mathrm{M}=\mathrm{Rh}(\mathrm{I}), \operatorname{Ir}(\mathrm{I}), \operatorname{Pt}(\mathrm{II})$ or $\operatorname{Pd}(\mathrm{II})$, deviate from the dictates of the electron-counting rules [29, 34, 56].
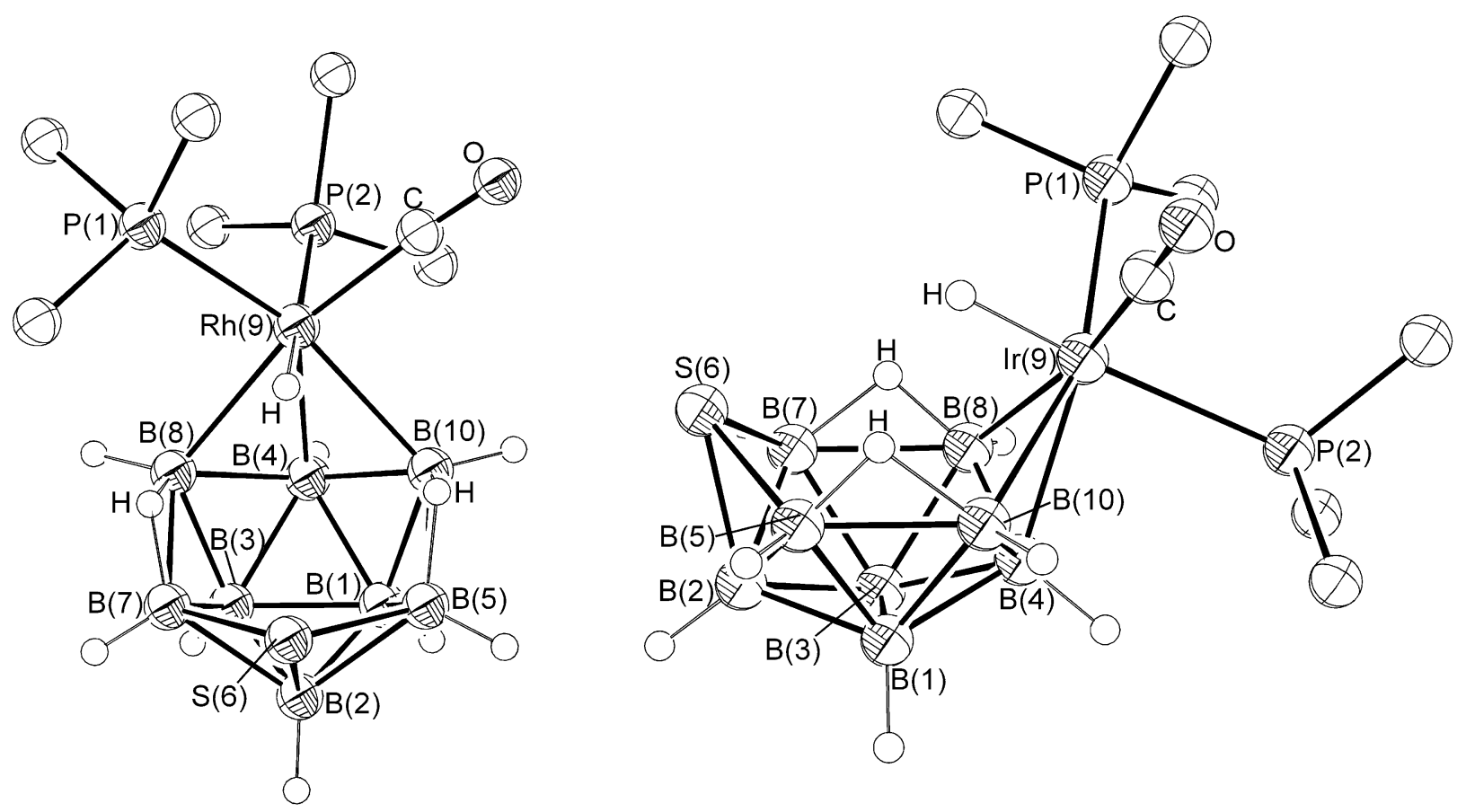
Figure 1 Molecular structures of $\mathbf{5}$ (right) and $\mathbf{6}$ (left). Only the methyl groups in $\mathbf{5}$ and the carbon atoms of the ipso-carbons for the phenyl rings in $\mathbf{6}$ are shown for clarity. Selected distances $(\AA)$ and interatomic angles $\left({ }^{\circ}\right)$ for $\mathbf{6}$ [with equivalent distances and angles for $\mathbf{5}$ in brackets] are as follow: $\mathrm{Rh}(9)-\mathrm{P}(1)$ 2.3711(5) [2.3192(15)], Rh(9)-P(2) 2.4599(5) [2.3661(16)], Rh(9)-C(1) 1.9095(19) [1.893(5)], $\mathrm{Rh}(9)-\mathrm{B}(4)$ 2.241(2) [2.245(7)], $\mathrm{Rh}(9)-\mathrm{B}(8)$ 2.288(2) [2.300(7)], $\mathrm{Rh}(9)-\mathrm{B}(10)$ 2.302(2) [2.293(8)], $\mathrm{Rh}(9)-\mathrm{H}(1)$ 1.55(3) [1.45(2)], C(1)-O 1.136(3) [1.139(6)]. Angles (deg.): P(1)-Rh(9)$\mathrm{P}(2)$ 103.33(2) [97.84(5)], $\mathrm{P}(1)-\mathrm{Rh}(9)-\mathrm{C}(1)$ 95.39(5) [95.14(16)], $\mathrm{P}(2)-\mathrm{Rh}(1)-\mathrm{C}(1)$ 89.02(5) [89.77(17)], $\mathrm{P}(1)-\mathrm{Rh}(9)-\mathrm{H}(1)$ 74.3(12) [83(3)], $\mathrm{P}(2)-\mathrm{Rh}(9)-\mathrm{H}(1)$ 176.1(13) [174(3)].

The ${ }^{11} \mathrm{~B}-\left\{{ }^{1} \mathrm{H}\right\}$ NMR spectra of the $\mathrm{PPh}_{3}$ ligated compounds, 6 and 7 , show six signals of 1:1:2:2:1:1 relative intensity ratio. In the ${ }^{1} \mathrm{H}-\left\{{ }^{11} \mathrm{~B}\right\}$ NMR spectra, however, there are two sets of boron-bound proton resonances due to the presence of two different isomers in solution (Tables 1 and 2). The major isomer (ca. 88\%) exhibits eight $\mathrm{BH}$ terminal and two BHB bridging proton signals that conform to the asymmetric structure found in the solid state; whereas the minor isomer shows only three $\mathrm{BH}$-terminal and one BHB-bridging proton resonances, suggesting that the other expected $\mathrm{BH}_{\mathrm{t}}$ signals overlap with those of the major isomers, as it is also found in the ${ }^{11} \mathrm{~B}$ NMR spectrum. The existence of a mixture of isomers is further confirmed in the ${ }^{31} \mathrm{P}-\left\{{ }^{1} \mathrm{H}\right\}$ spectrum, which for 6 exhibits two doublets of doublets for the major isomer at $\delta_{\mathrm{P}} 13.5$ and $28.4 \mathrm{ppm}$, and a doublet for the minor at $35.3 \mathrm{ppm}$; whereas for 7 , the spectrum shows two singlets for the major isomer at $\delta_{\mathrm{P}} 1.0$ and $-16.6 \mathrm{ppm}$, and a singlet at $6.4 \mathrm{ppm}$ for the minor component. In addition, the resonances of the $\mathrm{M}-\mathrm{H}$ hydride ligands are found at high field in the proton NMR spectra. Thus, diagnostic of the stereochemistry around the metal as well as the commented presence of two isomers, $\mathbf{6}$ exhibits a doublet of pseudo-triplets at $\delta_{\mathrm{H}}-14.65 \mathrm{ppm}$ and a broad multiplet at $-12.80 \mathrm{ppm}$ in a 7:1 relative intensity ratio, corresponding to the asymmetric and symmetric isomers, respectively. The large ${ }^{2} J_{\mathrm{P}-\mathrm{H}}$ coupling constant of $173.0 \mathrm{~Hz}$ found for the major isomer, demonstrates that, as found in the solid state, one of the $\mathrm{PPh}_{3}$ ligands is trans to the hydride (Figure 1); the pseudo-triplets indicate that the ${ }^{2} J_{\mathrm{P}-\mathrm{H}}$ coupling constant of the other phosphine, cis to the hydride ligand, is close to the value of 14 
Hz measured for the ${ }^{1} J_{\mathrm{Rh}-\mathrm{H}}$ coupling constant. The broadness of the hydride resonance of the minor symmetric isomer arises probably because the coupling constants of the ${ }^{1} \mathrm{H}$ hydride with ${ }^{103} \mathrm{Rh}$ and the two equivalent ${ }^{31} \mathrm{P}$ nuclei of the $\mathrm{PPh}_{3}$ ligands are similar.

The ${ }^{1} \mathrm{H}$ NMR spectrum of 7 shows a doublet of doublets at $\delta_{\mathrm{H}}-15.24 \mathrm{ppm}$ and a triplet at -13.05 ppm for the major and minor isomer, respectively, in a 5:1 relative intensity ratio that resembles the results found for the rhodathiaborane analogue, $\mathbf{6}$. These spectroscopic data suggest that the isomers correspond to two different conformations of the $\left\{\mathrm{M}(\mathrm{CO})(\mathrm{H})\left(\mathrm{PPh}_{3}\right)_{2}\right\}$ vertex with respect to the $\left\{\eta^{3}\right.$ $\mathrm{SB}_{8} \mathrm{H}_{10}$ f fragment: one asymmetric (found in the solid state) and the other with a $C_{\mathrm{s}}$ symmetry, schematics I and II.
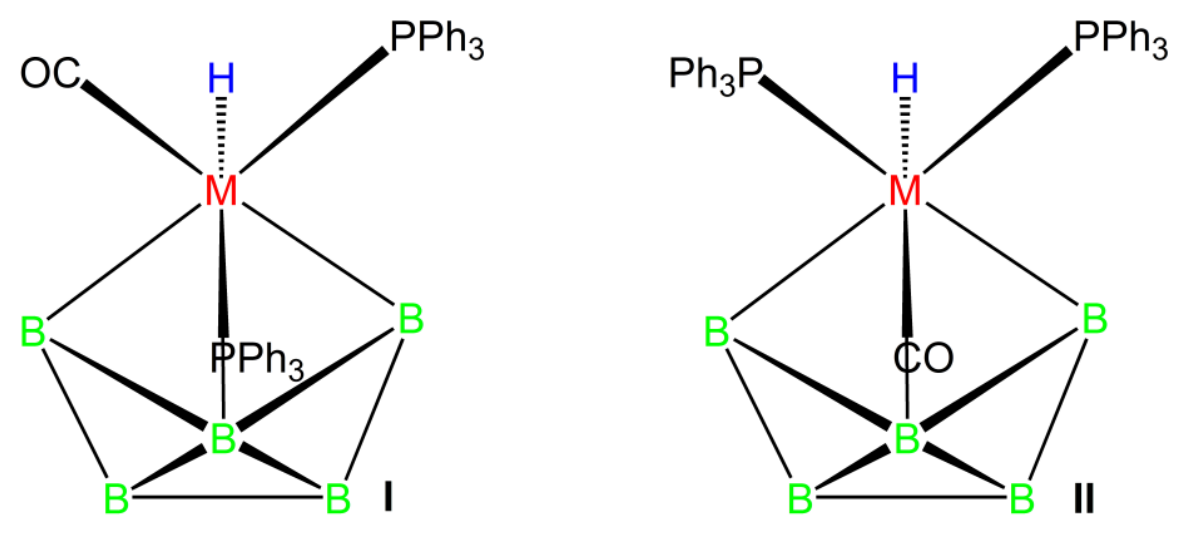

Variable temperature NMR experiments between room temperature and $120^{\circ} \mathrm{C}$ did not reveal interconversion between the conformers suggesting that there is no dynamic equilibrium in solution. and thus the transition state energy of a $\left\{\mathrm{M}(\mathrm{CO})(\mathrm{H})(\mathrm{L})_{2}\right\}$-to- $\left\{\eta^{3}-\mathrm{SB}_{8} \mathrm{H}_{10}\right\}$ conformational change in 6 and 7 is relative high.

The NMR data for the $\mathrm{PMe}_{3}$ ligated 5 reveal the presence of only one isomer in solution with an asymmetric structure that matches the stereochemistry found in the solid state (Figure 1). In agreement with this, the ${ }^{31} \mathrm{P}-\left\{{ }^{1} \mathrm{H}\right\}$ NMR spectrum exhibits a pair of doublets at $\delta\left({ }^{31} \mathrm{P}\right)-53.8 \mathrm{ppm}$ (sharp) and -47.9 ppm (broad); whereas the ${ }^{1} \mathrm{H}$ NMR spectrum shows a doublet of doublets at $\delta_{\mathrm{H}}$ $13.69 \mathrm{ppm}$.

\section{Scheme 3}



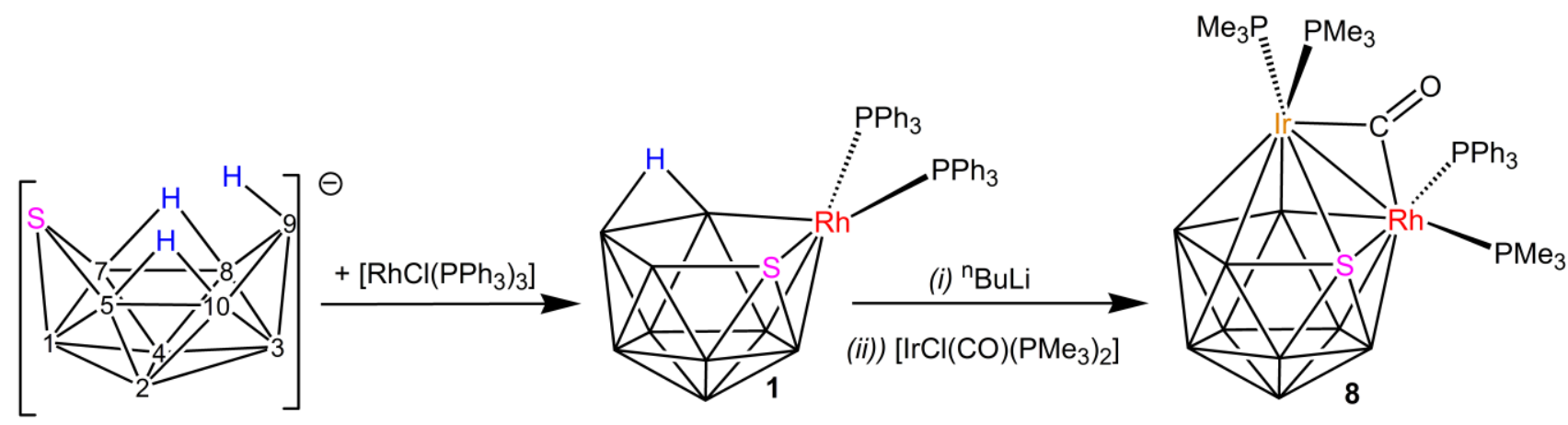

[arachno-4-SB $\left.{ }_{9} \mathrm{H}_{12}\right]^{-}$

We have a current interest in bimetalladodecaborane clusters, $\left[\left(\mathrm{PMe}_{2} \mathrm{Ph}_{4} \mathrm{M}_{2} \mathrm{~B}_{10} \mathrm{H}_{10}\right]\right.$ where $\mathrm{M}_{2}=$ $\mathrm{Pt}_{2}, \mathrm{PtPd}_{\text {, }} \mathrm{Pd}_{2}$, as these have an ability to reversibly sequester small molecules such as $\mathrm{O}_{2}, \mathrm{CO}$ and $\mathrm{SO}_{2}$ to afford [( $\left.\left.\mathrm{PMe}{ }_{2} \mathrm{Ph}\right)_{4}\left(\mathrm{O}_{2}\right) \mathrm{M}_{2} \mathrm{~B}_{10} \mathrm{H}_{10}\right],\left[\left(\mathrm{PMe}_{2} \mathrm{Ph}\right)_{4}(\mu-\mathrm{CO}) \mathrm{M}_{2} \mathrm{~B}_{10} \mathrm{H}_{10}\right]$, etc. [57]. In changing the metal from $\mathrm{Pt}_{2}$ to $\mathrm{Pd}_{2}$, the strength of the bonding of the small molecules to the metal-metal vector weakens as shown by the infrared stretching frequency of the bridging $\mathrm{CO}$, with the trend being well modelled by density functional theory (DFT) calculations as shown in Figure 2. The system comprises three components: the metal, the ligand, and the boron cluster; each independently tuneable to achieve the desired sensitivity of small molecule uptake and release. DFT calculation at the B3LYP/6-31G*/LANL2DZ level show that, whereas changing the metal from Pt to Pd would weaken the binding, an $\left\{\mathrm{IrRhSB}_{9} \mathrm{H}_{9}\right\}$ cluster would increase the binding strength (Figure 2). It was therefore of interest to prepare such a compound and to compare the measured and calculated IR CO stretching frequency. 


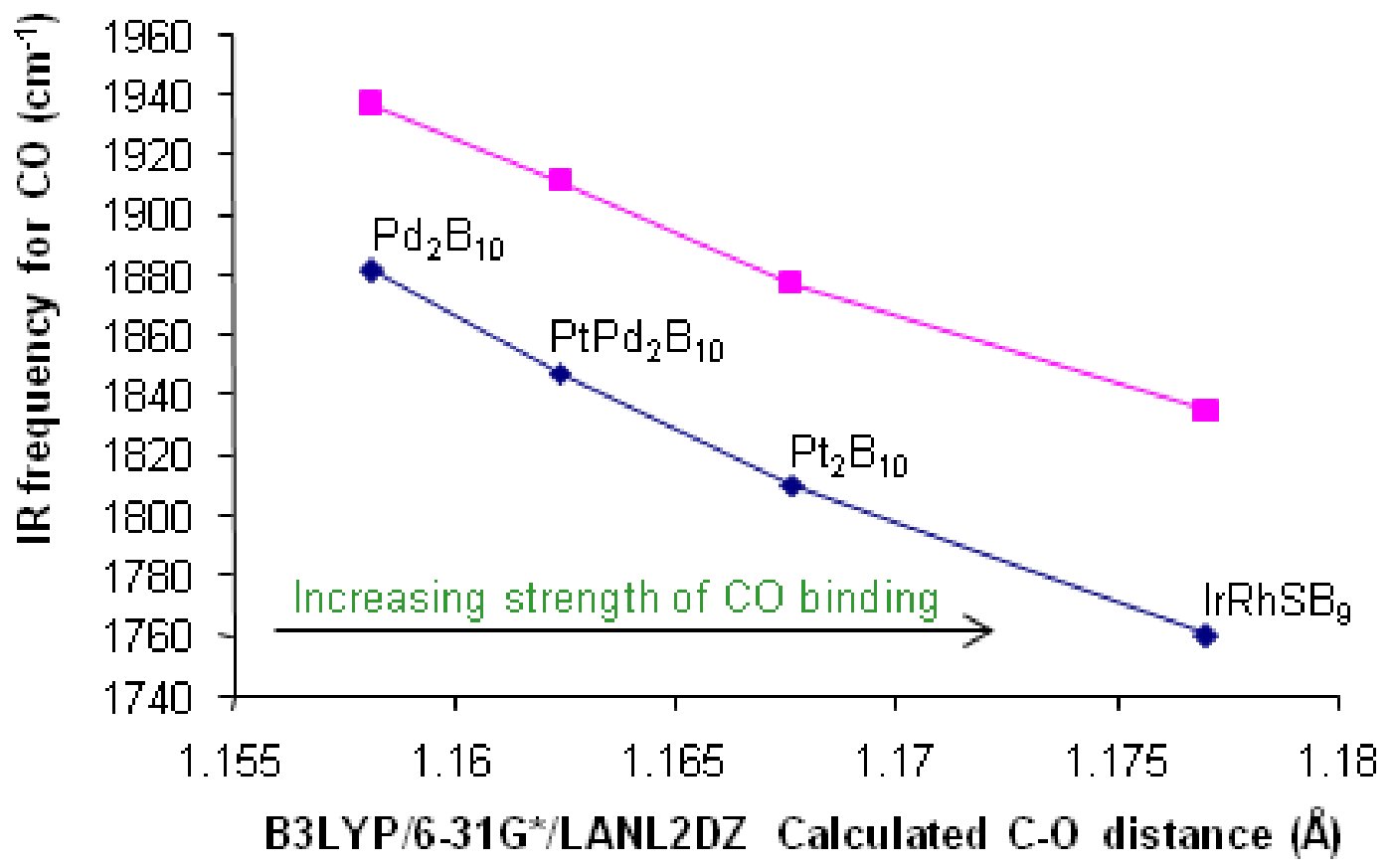

Figure 2. Measured (lower line) and DFT-calculated (upper line) infrared stretching frequencies of the $\mathrm{Pt}_{2} \mathrm{~B}_{10}-\mathrm{CO}, \mathrm{PtPdB}_{10}-\mathrm{CO}$ and $\mathrm{Pd}_{2} \mathrm{~B}_{10}-\mathrm{CO}$, (from reference [57]) plotted against the $\mathrm{B} 3 \mathrm{LYP} / 6$ $31 \mathrm{G}^{*} / \mathrm{LANL} 2 \mathrm{DZ}$ calculated C-O distance together with $\mathrm{CO}$ group in $\mathrm{IrRhSB}{ }_{9} \mathrm{CO}(\mathbf{8})$ with the binding strength of the metal-metal vector to the $\mathrm{CO}$ molecules increasing to the right.

Thus, it is convenient to report here on a carbonyl ligated bimetallathiaborane obtained from $[8,8$ $\left.\left(\mathrm{PPh}_{3}\right)_{2}-8,7-\mathrm{RhSB}_{9} \mathrm{H}_{10}\right]$ 1. The $\mathrm{BHB}$ bridging hydrogen atom in 1 undergoes deprotonation with strong bases to afford the 11-vertex closo-anion, [8,8-( $\left.\left.\mathrm{PPh}_{3}\right)_{2}-8,7-\mathrm{RhSB}_{9} \mathrm{H}_{9}\right]^{-}$[40], and this has the potential to react with other metal complexes to produce 12-vertex bimetallathiadodecaborane clusters. Treatment of 1 with ${ }^{\mathrm{n}} \mathrm{BuLi}$ and the addition of $\left[\mathrm{IrCl}(\mathrm{CO})\left(\mathrm{PMe}_{3}\right)_{2}\right]$, resulted in the isolation of the 12-vertex bimetallic iridarhodathiaborane, [1,2-( $\mu-\mathrm{CO})-1,1,2-\left(\mathrm{PMe}_{3}\right)_{3}-2-\left(\mathrm{PPh}_{3}\right)-$ closo-1,2$\left.\mathrm{IrRhSB}_{9} \mathrm{H}_{9}\right](\mathbf{8})$ in a low, $0.70 \%$, yield (Scheme 3). The compound is characterised by NMR and IR spectroscopies, and by a single-crystal X-ray diffraction study (Figure 3) which show that there has been ligand exchange between the $\mathrm{PMe}_{3}$ and $\mathrm{PPh}_{3}$ during the reaction. The yield is low and the use of $\mathrm{KHBEt}_{3}$ as the deprotonating reagent or a converse synthesis by the addition of $\left[\left(\mathrm{PPh}_{3}\right)_{3} \mathrm{RhCl}\right]$ to the anion of $\left[8,8,8-(\mathrm{CO})\left(\mathrm{PMe}_{3}\right)_{2}-8,7-\mathrm{IrSB}_{9} \mathrm{H}_{10}\right] 4$ does not improve yield of the dimetallathiaborane. 


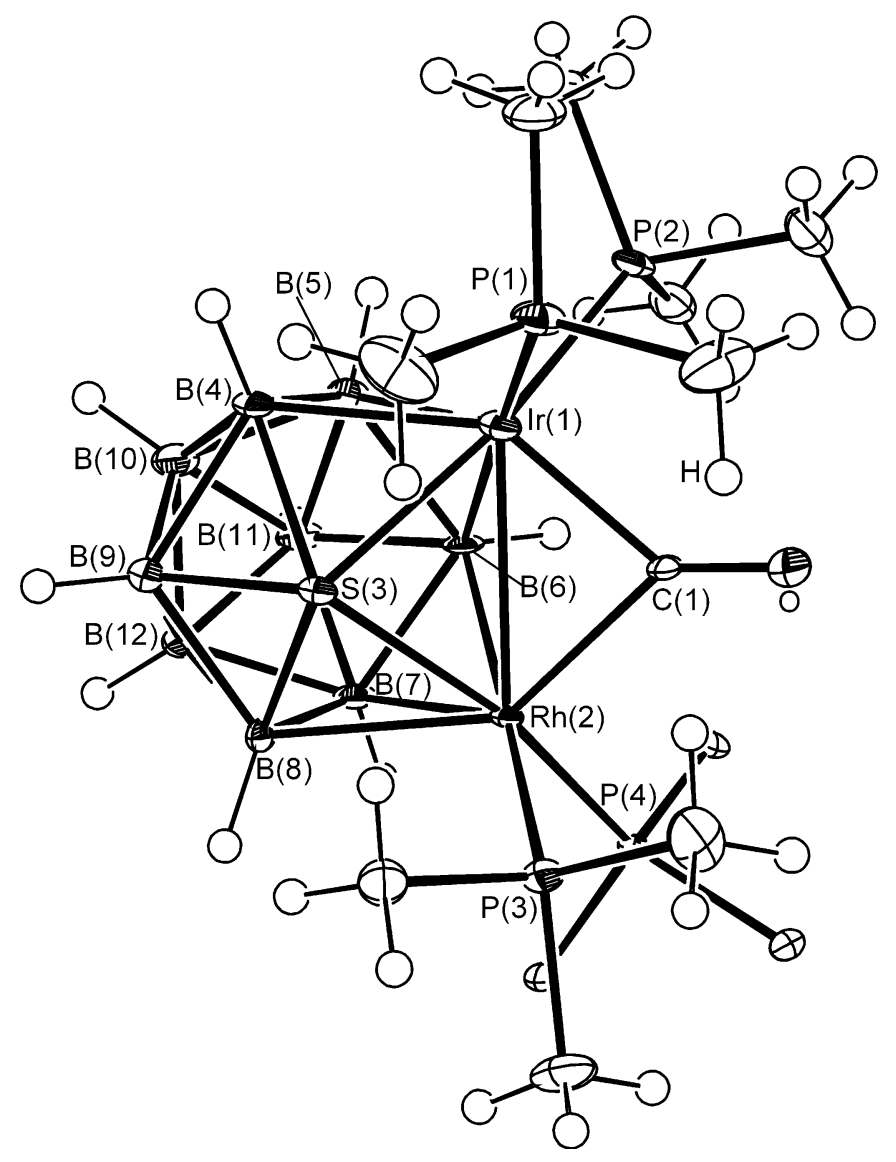

Figure 3. Molecular structure of 8. Only the ipso-carbons for the phenyl rings are shown for clarity. Selected bond lengths $(\AA)$ and interatomic angles $\left(^{\circ}\right)$ : $\operatorname{Ir}(1)-\operatorname{Rh}(2) 2.7583(4), \operatorname{Ir}(1)-\mathrm{P}(1) 2.3262(10)$, $\operatorname{Ir}(1)-\mathrm{P}(2)$ 2.2752(10), $\mathrm{Rh}(2)-\mathrm{P}(3)$ 2.3533(11), $\mathrm{Rh}(2)-\mathrm{P}(4)$ 2.2723(10), $\operatorname{Ir}(1)-\mathrm{S}(3)$ 2.4422(9), $\mathrm{Rh}(2)-$ $\mathrm{S}(3)$ 2.4434(9), $\operatorname{Ir}(1)-\mathrm{C}(1)$ 2.040(4), $\mathrm{Rh}(2)-\mathrm{C}(1)$ 2.097(3), C(1)-O 1.172(5), $\mathrm{P}(1)-\operatorname{Ir}(1)-\mathrm{P}(2)$ 93.16(4), $\mathrm{P}(3)-\mathrm{Rh}(2)-\mathrm{P}(4)$ 94.30(4), $\operatorname{Ir}(1)-\mathrm{C}(1)-\mathrm{Rh}(2)$ 83.60(14), $\mathrm{P}(1)-\operatorname{Ir}(1)-\mathrm{Rh}(2)$ 119.45(3), $\mathrm{P}(2)-\operatorname{Ir}(1)-\operatorname{Rh}(2)$ 128.42(3), $\mathrm{P}(3)-\mathrm{Rh}(2)-\operatorname{Ir}(1)$ 118.97(3), $\mathrm{P}(4)-\mathrm{Rh}(2)-\operatorname{Ir}(1)$ 131.29(2), $\operatorname{Ir}(1)-\mathrm{C}(1)-\mathrm{O} 139.0(3), \mathrm{Rh}(2)-$ $\mathrm{C}(1)-\mathrm{O} 137.4(3)$.

Compound $\mathbf{8}$ is a new member in the series of 12-vertex metallathiaboranes built upon the $\left\{\mathrm{SB}_{9} \mathrm{H}_{9}\right\}$ scaffold $[26,37,38,42,58-61]$. Among these bimetallic clusters, the rhodathiaboranes, [2(Cl)-2,3-( $\mu$-Cl)-2,3-( $\left.\mathrm{PPh}_{3}\right)_{2}-3-\left(3,7-\mu{ }^{\mathrm{C}, \mathrm{P}}\left(\mathrm{C}_{6} \mathrm{H}_{4} \mathrm{PPh}_{2}\right)-\right.$ closo-2,3,1- $\left.\mathrm{Rh}_{2} \mathrm{SB}_{9} \mathrm{H}_{8}\right]$ (9) [42], [2,3-(CO) $)_{2}-2,3-$ $(\mu-\mathrm{CO})-2,3-\left(\mathrm{PPh}_{3}\right)_{2}-$ closo-2,3,1- $\left.\mathrm{Rh}_{2} \mathrm{SB}_{9} \mathrm{H}_{9}\right](\mathbf{1 0})[60]$ and $\left[2,3-(\mathrm{Cl})_{2}-2,3-(\mu-\mathrm{Cl})-2-\mathrm{PPh}_{3}-3,7-(\mu-\right.$ dppm)-closo-2,3,1- $\left.\mathrm{Rh}_{2} \mathrm{SB}_{9} \mathrm{H}_{8}\right]$ (11) [61], have been crystallographically determined. These clusters exhibit a triangular $\left\{\mathrm{M}_{2} \mathrm{~S}\right\}$ face with the M-M edge being bridged by either a chlorine or a $\mathrm{CO}$ ligand. In the rhodathiaboranes, 9-11, the Rh-Rh distance changes from the values of 2.6307(9) and 2.592(1) $\AA$, found for the Cl-ligated bimetallic clusters, 9 and 11, to the distances of 2.7409(10) and 
2.7583(4) A of the CO-ligated counterparts, 8 and 10, respectively. The $\mu$-CO-to- $\{\operatorname{Ir}-\mathrm{Rh}\}$ linkage in 8 is asymmetric with the C-Ir distance $0.057(4) \AA$ shorter than the corresponding C-Rh length: this may reflect a higher electron density at the iridium centre.

It is noteworthy that in $\mathbf{8}$, the Rh-P bond distances of the phosphine ligands trans to the sulphur vertex $\left[\mathrm{P}(2)\right.$ and $\mathrm{P}(4)$ in Figure 1] are shorter than the corresponding Rh-P bond lengths of the $\mathrm{PR}_{3}$ ligands that lie trans to the $\mathrm{B}(6)$ vertex $[\mathrm{P}(1)$ and $\mathrm{P}(3)$ in Figure 1]. This suggests a higher trans influence of a B-H unit vs. a sulphur vertex. This fact has also been observed in 1, and in 11-vertex nido-hydridorhodathiaborane derivatives [29, 31].

The addition of the calculated and measured IR stretching frequency data of the bridging $\mathrm{CO}$ to the plot in Figure 2 for the $\left[\left(\mathrm{PMe}_{2} \mathrm{Ph}\right)_{4} \mathrm{M}_{2} \mathrm{~B}_{10} \mathrm{H}_{10}\right]$ compounds shows that it fits quite well into an almost linear progression of increasing binding strength of the $\mathrm{CO}$ ligand to the $\mathrm{M}-\mathrm{M}$ vector in the order $\mathrm{Pd}_{2}$ $>\mathrm{PtPd}>\mathrm{Pt}_{2}>\operatorname{IrRh}$ 8. However, the increased binding strength is such that the CO ligand is now irreversibly bound. In contrast to the $\mathrm{Pt} / \mathrm{Pd}$ compounds, which show reversible loss of the CO ligand by heating or by photolysis [57], no such activity is apparent for $\mathbf{8}$. Additionally, the decarbonylating agent $\mathrm{Me}_{3} \mathrm{NO}$, which, for example, affords quantitatively decarbonylation of the monometallathiaborane $\left[8,8,8-(\mathrm{CO})\left(\mathrm{PMe}_{3}\right)_{2}-8,7-\mathrm{IrSB}_{9} \mathrm{H}_{10}\right] 4$ [62], is inactive here. However, since the binding of small molecules across the MM' vector in the 12-vertex metallaboranes is tunable [55, $63,64]$, a systematic modification of the metal centers in bimetallic $\left\{\mathrm{MM}^{\prime} \mathrm{SB}_{9}\right\}$ systems could similarly induce reversibility. There is potential here for these B-frame bimetallics to become catalyst precursors in the activation of small molecules.

\section{Conclusion}

The treatment of the 9-vertex anion [arachno-4- $\left.\mathrm{SB}_{8} \mathrm{H}_{11}\right]^{-}$with $\left[\mathrm{MCl}(\mathrm{CO})\left(\mathrm{PPh}_{3}\right)_{2}\right]$, where $\mathrm{M}=\mathrm{Rh}$ or Ir, is shown to be a convenient synthetic route for the formation of new 10-vertex arachnometallathiaboranes $\left[9,9,9,9-(\mathrm{CO})(\mathrm{H})\left(\mathrm{PPh}_{3}\right)_{2}\right.$-arachno-9,6- $\left.\mathrm{MSB}_{8} \mathrm{H}_{10}\right]$ in good yields. Alternatively, the 10-vertex anion [arachno-6- $\left.\mathrm{SB}_{9} \mathrm{H}_{12}\right]^{-}$allows the formation of the 10-vertex iridathiaborane analogue, $\left[9,9,9,9-(\mathrm{CO})(\mathrm{H})\left(\mathrm{PMe}_{3}\right)_{2}\right.$-arachno-9,6-IrSB $\left.{ }_{8} \mathrm{H}_{10}\right](5)$, via cluster dismantling. The irida- 
and rhodathiadecaboranes are the first Group 9 metallathiaboranes based on the $\left\{\eta^{3}-\mathrm{SB}_{8} \mathrm{H}_{10}\right\}$ moiety that have been characterized by X-ray diffraction.

The preparation of [1,2-( $\mu-\mathrm{CO})-1,1,2-\left(\mathrm{PMe}_{3}\right)_{3}-2-\left(\mathrm{PPh}_{3}\right)$-closo-1,2- $\left.\mathrm{IrRhSB}_{9} \mathrm{H}_{9}\right] \mathbf{8}$ demonstrates that deprotonation of $\left[\left(\mathrm{PPh}_{3}\right)_{2} \mathrm{RhSB}_{9} \mathrm{H}_{10}\right] \mathbf{1}$ with strong bases and subsequent treatment with transition element complexes open the door to the synthesis of bimetallic 12-vertex clusters. Although the yield of $\mathbf{8}$ is low, the route could, in principle, be improved or it could work better with other metal complexes. Given the interesting reactivity found in $\left[\left(\mathrm{PMe}_{2} \mathrm{Ph}\right)_{4} \mathrm{MM}^{\prime} \mathrm{B}_{10} \mathrm{H}_{10}\right]\left(\right.$ where $\mathrm{MM}^{\prime}=\mathrm{PtPt}$, $\mathrm{PtPd}, \mathrm{PdPd})[57,63,64]$, the assembly of two metal centres on the $\left\{\mathrm{SB}_{9} \mathrm{H}_{9}\right\}$ scaffold could generate systems with a reactivity that may complement the reversible binding of small molecules observed in 12-vertex bimetallic platina- and palladaboranes.

\section{Experimental}

\subsection{General Procedures}

Reactions were carried out under an argon atmosphere using standard Schlenk-line techniques. Solvents were obtained dried from a Solvent Purification System of Innovative Technnology Inc. The thiaborane reagents, arachno-4- $\mathrm{SB}_{8} \mathrm{H}_{12}$ and $\mathrm{Cs}\left[\right.$ arachno-6- $\left.\mathrm{SB}_{9} \mathrm{H}_{12}\right][27,28]$, and the metal complexes [ $\left.\mathrm{RhCl}(\mathrm{CO})\left(\mathrm{PPh}_{3}\right)_{2}\right]$ [65], [ $\left.\operatorname{IrCl}(\mathrm{CO})\left(\mathrm{PPh}_{3}\right)_{2}\right]$ [66], and [ $\left.\operatorname{IrCl}(\mathrm{CO})\left(\mathrm{PMe}_{3}\right)_{2}\right]$ [67] were prepared according to the literature methods. Proton Sponge was purchased from Aldrich and used as received. Preparative thin-layer chromatography (TLC) was carried out using $1 \mathrm{~mm}$ layers of silca gel G (Fluka, type GF254) made from water slurries on glass plates of dimensions $20 \times 20 \mathrm{~cm}$ and dried in air at $25^{\circ} \mathrm{C}$. Infrared spectra were recorded on a Perkin-Elmer Spectrum 100 spectrometer, using an Universal ATR Sampling Accessory. NMR spectra were recorded on Bruker Avance 300MHz and AV 400-MHz spectrometers, using ${ }^{11} \mathrm{~B},{ }^{11} \mathrm{~B}-\left\{{ }^{1} \mathrm{H}\right\},{ }^{1} \mathrm{H},{ }^{1} \mathrm{H}-\left\{{ }^{11} \mathrm{~B}\right\}$ and ${ }^{1} \mathrm{H}-\left\{{ }^{11} \mathrm{~B}(\right.$ selective $\left.)\right\}$ techniques. ${ }^{1} \mathrm{H}$ NMR chemical shifts were measured relative to partially deuterated solvent peaks but are reported in ppm relative to tetramethylsilane. ${ }^{11} \mathrm{~B}$ chemical shifts are quoted relative to $\left.\left[\mathrm{BF}_{3}(\mathrm{OEt})_{2}\right)\right]$ and ${ }^{31} \mathrm{P}$ chemical shifts are quoted relative to $85 \%$ aqueous $\mathrm{H}_{3} \mathrm{PO}_{4}$. Mass spectrometric data were recorded on a MICROFLEX instrument operating in either positive or negative modes, 
using matrix-assisted laser desorption/ionization (MALDI). A nitrogen laser of $337 \mathrm{~nm}$ (photon energy of $3.68 \mathrm{eV}$ ) was used for the ionization processes, and the molecules under study were protected with a matrix of trans-2-[3-(4-tert-butylphenyl)-2-methyl-2-propenylidene]malononitrile (DCTB).

\subsection{Synthesis of $\left[9,9,9,9-(\mathrm{CO})(\mathrm{H})\left(\mathrm{PMe}_{3}\right)_{2}\right.$-arachno-9, 6- $\left.\mathrm{IrSB} \mathrm{B}_{8} \mathrm{H}_{10}\right]$ (5)}

Compound 5 was prepared according to the reaction described previously for the preparation of $\left[8,8,8-(\mathrm{CO})\left(\mathrm{PMe}_{3}\right)_{2}\right.$-nido-8, 7- $\left.\mathrm{IrSB}_{9} \mathrm{H}_{10}\right]$ (4) from the reaction of $\mathrm{CsSB}_{9} \mathrm{H}_{12}$ and $\left[\mathrm{Ir} \mathrm{Cl}(\mathrm{CO})\left(\mathrm{PMe}_{3}\right)_{2}\right]$ in THF solution [60]. In the original preparation, $\mathrm{TLC}\left(\mathrm{GF}_{254}\right.$ silica gel) plating of the reaction mixture in $\mathrm{CH}_{2} \mathrm{Cl}_{2}$ /hexane, 80:20 afforded two bands: a pale yellow band $\mathrm{R}_{\mathrm{F}} 0.4$ identified as 4 (71\%) and a colourless UV active band, $\mathrm{R}_{\mathrm{F}} 0.7$, which was not identified at that time. Subsequent work has now identified the UV active band as 5. $0.392 \mathrm{~g}(0.14 \mathrm{mmol})$ of $\mathrm{CsSB}_{9} \mathrm{H}_{12}$ and $0.573 \mathrm{~g}$ $(0.14 \mathrm{mmol})$ of $\left[\mathrm{IrCl}(\mathrm{CO})\left(\mathrm{PMe}_{3}\right)_{2}\right]$ affords $0.047 \mathrm{~g}(0.0094 \mathrm{mmol})$ of $5(6.7 \%) . \delta\left({ }^{11} \mathrm{~B}\right)\left[\delta\left({ }^{1} \mathrm{H}\right)\right.$ in brackets $]\left(\mathrm{CDCl}_{3}, 298 \mathrm{~K}\right) 1 \mathrm{BH}+23.6[+4.78, J 32.1 \mathrm{~Hz}], 1 \mathrm{BH}+10.5[+5.03], 2 \mathrm{BH}+8.1[+2.81], 1 \mathrm{BH}$ $-29.1[+0.61], 1 \mathrm{BH}-29.8[+1.01],-31.5[+1.59],-33.2[+1.46] .{ }^{1} \mathrm{H}$ NMR $\left(300 \mathrm{MHz} ; \mathrm{CDCl}_{3} ; 298 \mathrm{~K}\right): \delta$ $\operatorname{Ir}-H-13.69\left[\mathrm{dd}, J\left({ }^{103} \mathrm{P}-{ }^{1} \mathrm{H}\right)=141 \mathrm{~Hz},{ }^{2} J\left({ }^{31} \mathrm{P}-{ }^{1} \mathrm{H}\right)=21.9 \mathrm{~Hz}\right],+1.90\left[\mathrm{~d},{ }^{2} J\left({ }^{31} \mathrm{P}-{ }^{1} \mathrm{H}\right)=9.2 \mathrm{~Hz}\right.$, $\left.\mathrm{PMe}_{3}\right],+1.52\left[\mathrm{~d},{ }^{2} J\left({ }^{31} \mathrm{P}-{ }^{1} \mathrm{H}\right)=9.2 \mathrm{~Hz}, \mathrm{PMe} e_{3}\right] .{ }^{31} \mathrm{P}-\left\{{ }^{1} \mathrm{H}\right\} \mathrm{NMR}\left(161 \mathrm{MHz} ; \mathrm{CDCl}_{3} ; 223 \mathrm{~K}\right): \delta-53.8[$ $\left.\mathrm{d},{ }^{2} J\left({ }^{31} \mathrm{P}-{ }^{31} \mathrm{P}\right)=20 \mathrm{~Hz}, \mathrm{P}(2)\right],-47.9$ [broad, $\left.\mathrm{P}(1)\right]$. Analysis Found(Calc.): C 16.72(16.75), H 5.85(5.82). IR(ATR): $v_{\max } / \mathrm{cm}^{-1} 2554-2501 \mathrm{~s}(\mathrm{BH}),(\mathrm{IrH}), 2014 \mathrm{~s}(\mathrm{IrCO})$.

\subsection{Synthesis of $\left[9,9,9,9-(C O)(H)\left(P P h_{3}\right)_{2}\right.$-arachno-9,6- RhSB $\left._{8} H_{10}\right](6): 60.0 \mathrm{mg}(0.47 \mathrm{mmol})$ of} arachno-4- $\mathrm{SB}_{8} \mathrm{H}_{12}$, placed in a Schlenk tube, was dissolved in $10 \mathrm{~mL}$ of dry $\mathrm{Et}_{2} \mathrm{O}$ under an atmosphere of argon. The tube, closed with a rubber septum, was immersed in liquid nitrogen, and an equimolar amount of $\mathrm{MeLi}\left(1.6 \mathrm{M}^{\text {in }} \mathrm{Et}_{2} \mathrm{O}\right)$ was injected with a syringe (through the septum). The resulting milky suspension was stirred for 5 minutes. Then, $325 \mathrm{mg}(0.47 \mathrm{mmol})$ of $\left[\mathrm{RhCl}(\mathrm{CO})\left(\mathrm{PPh}_{3}\right)_{2}\right]$ was added and the reaction mixture was stirred at room temperature under an atmosphere of argon. After the first hour, there was formation of a beige precipitate; but the stirring was maintained for another 4 hours. The resulting suspension was filtered through a frit, the solid washed with pentane, and dried under vacuum for 8 hours. The product was finally crystallized from $\mathrm{CH}_{2} \mathrm{Cl}_{2} /$ hexane to give $230 \mathrm{mg}$ of $6(62 \%) .{ }^{11} \mathrm{~B}$ and ${ }^{1} \mathrm{H}$ NMR data are gathered in Table 1 , and 
additional spectroscopic data are reported here: IR(ATR): $v_{\max } / \mathrm{cm}^{-1} 2554-2502 \mathrm{~s}(\mathrm{BH}), 2030 \mathrm{~s}$ (RhCO), $2010 \mathrm{~m}$ (RhCO). ${ }^{1} \mathrm{H}-\left\{{ }^{11} \mathrm{~B}\right\}$ NMR (300 MHz; $\left.\mathrm{CD}_{2} \mathrm{Cl}_{2} ; 298 \mathrm{~K}\right): \delta 7.45-6.97$ (30H, aromatic, $\left.2 \mathrm{PPh}_{3}\right) .{ }^{31} \mathrm{P}-\left\{{ }^{1} \mathrm{H}\right\}$ NMR $\left(161 \mathrm{MHz} ; \mathrm{CDCl}_{3} ; 223 \mathrm{~K}\right): \delta 13.5\left(\mathrm{dd},{ }^{1} J_{\mathrm{Rh}-\mathrm{P}}=75 \mathrm{~Hz},{ }^{2} J_{\mathrm{PP}}=24 \mathrm{~Hz}\right.$; major component), 28.4 (dd, ${ }^{1} J_{\mathrm{Rh}-\mathrm{P}}=108 \mathrm{~Hz},{ }^{2} J_{\mathrm{P}-\mathrm{P}}=24 \mathrm{~Hz}$; major component), 35.3 (d, ${ }^{1} J_{\mathrm{Rh}-\mathrm{P}}=107 \mathrm{~Hz}$; minor component). $m / z$ (MALDI) $492\left[\mathrm{M} \mathrm{-} \mathrm{(CO)} \mathrm{-}\left(\mathrm{PPh}_{3}\right)-3 \mathrm{H}\right]^{+}$; isotope envelope. $\mathrm{C}_{37} \mathrm{H}_{41} \mathrm{~B}_{8} \mathrm{O}_{1} \mathrm{P}_{2} \mathrm{Rh}_{1} \mathrm{~S}_{1}$ requires 785$]$.

Table $1{ }^{11} \mathrm{~B}$ and ${ }^{1} \mathrm{H}-\left\{{ }^{11} \mathrm{~B}\right\}$ NMR data for 6 in $\mathrm{CDCl}_{3}$ at $293 \mathrm{~K}$, compared to the corresponding DFT/GIAO-calculated ${ }^{11} \mathrm{~B}$-nuclear shielding values in [brackets].

\begin{tabular}{|c|c|c|}
\hline Assignment $^{\mathrm{a}}$ & $\delta\left({ }^{11} \mathrm{~B}\right)[\mathrm{DFT}]$ & $\delta\left({ }^{1} \mathrm{H}\right)$ (minor $)^{\mathrm{b}}$ \\
\hline $\mathrm{B}(4)$ & $30.9[32.5]$ & $5.52(5.94)$ \\
\hline $\mathrm{B}(2)$ & $14.4[16.3]$ & $3.65(2.39)$ \\
\hline $\mathrm{B}(6), \mathrm{B}(10)$ & $-7.8[-6.5]$ & $2.75,1.93(2.13)$ \\
\hline $\mathrm{B}(7), \mathrm{B}(9)$ & $-18.1[-7.7,-9.8]$ & $1.20,1.70$ \\
\hline $\mathrm{B}(3)$ & $-27.8[-22.9]$ & 1.40 \\
\hline $\mathrm{B}(1)$ & $-29.07[-27.9]$ & 1.02 \\
\hline B(6)-H-B(7), B(9)-H-B(10) & & $\cdot 1.10,-2.23(-1.40)$ \\
\hline $\mathrm{Rh}-\mathrm{H}$ & & $-14.65^{\mathrm{c}}(-12.80)^{\mathrm{d}}$ \\
\hline \multicolumn{3}{|c|}{$\begin{array}{l}{ }^{a} \text { Assignments based on }{ }^{1} \mathrm{H}\left\{{ }^{11} \mathrm{~B}\right\} \text { selective experiments and DFT /GIAO } \\
\text { calculated }{ }^{11} \mathrm{~B} \text { chemical shielding data. }{ }^{\mathrm{b}} \text { The chemical shifts for the minor } \\
\text { component are given in parenthesis. }{ }^{\mathrm{c}} \mathrm{Rh}-\mathrm{H}, \mathrm{dt}{ }^{1} J_{\mathrm{Rh}-\mathrm{H}}=14.0 \mathrm{~Hz},{ }^{2} J_{\mathrm{P}-\mathrm{H}}=173.1 \\
\mathrm{~Hz}\left[\mathrm{P}(2) \text { trans to the hydride ligand], }{ }^{2} J_{\mathrm{P}-\mathrm{H}} \approx 14 \mathrm{~Hz}[\mathrm{P}(1) \text { trans to the } \mathrm{B}(10)\right. \\
\text { vertex]. }{ }^{\mathrm{d}} \text { Broad signal that precludes the resolution of the multiplet: }{ }^{1} J_{\mathrm{Rh}-\mathrm{H}} \approx \\
2\left({ }^{2} J_{\mathrm{P}-\mathrm{H}}\right) \text { should give a pseudo-quartet. }\end{array}$} \\
\hline
\end{tabular}

\subsection{Synthesis of $\left[9,9,9,9-(\mathrm{CO})(\mathrm{H})\left(\mathrm{PPh}_{3}\right)_{2}\right.$-arachno-9, 6-IrSB $\left.{ }_{8} \mathrm{H}_{10}\right]$ (7)}

Following the procedure above for the synthesis of $6,205 \mathrm{mg}(61 \%)$ of the CO-ligated iridathiaborane analogue, 7, was isolated. ${ }^{11} \mathrm{~B}$ and ${ }^{1} \mathrm{H}$ NMR data are gathered in Table 2, and additional spectroscopic data are reported here: IR(ATR): $v_{\max } / \mathrm{cm}^{-1} 2554-2501 \mathrm{~s}(\mathrm{BH}), 2114 \mathrm{~m}$ (IrH), $2014 \mathrm{~s}$ (IrCO). ${ }^{1} \mathrm{H}-\left\{{ }^{11} \mathrm{~B}\right\} \mathrm{NMR}\left(300 \mathrm{MHz} ; \mathrm{CD}_{2} \mathrm{Cl}_{2} ; 298 \mathrm{~K}\right): \delta$ 7.72-6.95 (30H, aromatic, $\left.2 \mathrm{PPh}_{3}\right) .{ }^{31} \mathrm{P}-\left\{{ }^{1} \mathrm{H}\right\}$ NMR $\left(161 \mathrm{MHz} ; \mathrm{CDCl}_{3} ; 295 \mathrm{~K}\right): \delta 1.0\left[\mathrm{~d},{ }^{2} J\left({ }^{31} \mathrm{P}_{-}^{31} \mathrm{P}\right)=18 \mathrm{~Hz}\right.$, major component $]$, $-16.6\left[\mathrm{~d},{ }^{2} J\left({ }^{31} \mathrm{P}_{-}^{31} \mathrm{P}\right)=17 \mathrm{~Hz}\right.$, major component], 6.4 (s, minor component); $m / z$ (MALDI) 871 [M $3 \mathrm{H}]^{+} ; 842[\mathrm{M}-(\mathrm{CO})-4 \mathrm{H}]^{+}$; isotope envelope. $\mathrm{C}_{37} \mathrm{H}_{41} \mathrm{~B}_{8} \mathrm{O}_{1} \mathrm{P}_{2} \mathrm{Ir}_{1} \mathrm{~S}_{1}$ requires 874].

Table $2{ }^{11} \mathrm{~B}$ and ${ }^{1} \mathrm{H}-\left\{{ }^{11} \mathrm{~B}\right\}$ NMR data for 7 in $\mathrm{CDCl}_{3}$ at $293 \mathrm{~K}$, compared to the corresponding DFT/GIAO-calculated ${ }^{11}$ B-nuclear shielding values in [brackets].

\begin{tabular}{lll}
\hline Assignment $^{\mathrm{a}}$ & $\delta\left({ }^{11} \mathrm{~B}\right)[\mathrm{DFT}]$ & $\delta\left({ }^{1} \mathrm{H}\right)(\text { minor })^{\mathrm{b}}$ \\
\hline
\end{tabular}




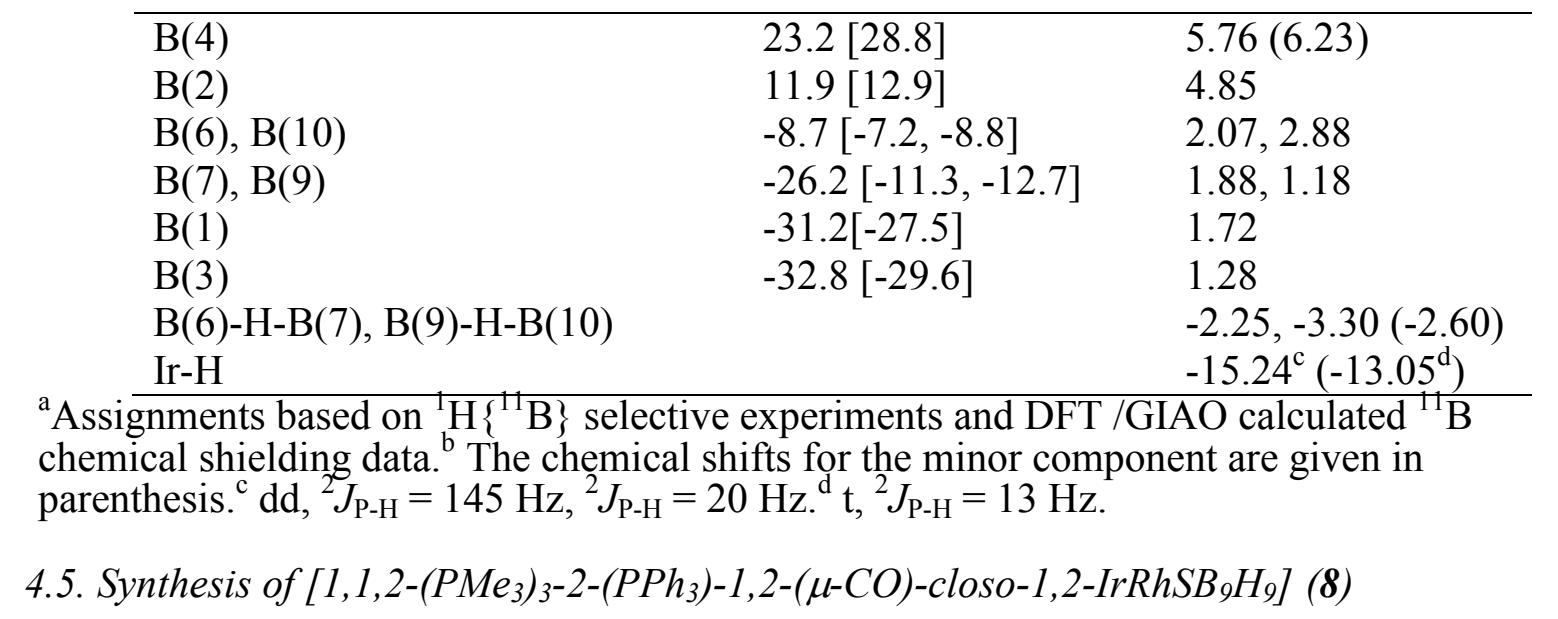

A two-neck round bottom flask containing $\left[\left(\mathrm{PPh}_{3}\right)_{2} \mathrm{RhSB}_{9} \mathrm{H}_{10}\right](\mathbf{1} ; 94.6 \mathrm{mg}, 123 \mu \mathrm{mol})$ was attached to the Schlenk line, evacuated and refilled with argon and then $10 \mathrm{ml}$ THF injected through a septum. The solution was cooled to $-70{ }^{\circ} \mathrm{C}$ and $0.08 \mathrm{ml}$ of $1.6 \mathrm{M} n \mathrm{BuLi}$ was added by syringe. The solution was allowed to warm to ambient temperature with stirring then $\left[\mathrm{IrCl}(\mathrm{CO})\left(\mathrm{PMe}_{3}\right)_{2}\right](50 \mathrm{mg}, 0.127$ mmol) was added against a flow of argon and the stirring continued overnight after which time it was filtered in air, applied to preparative TLC plates and developed in $70: 30 \mathrm{CH}_{2} \mathrm{Cl}_{2} /$ hexane giving one orange colored band, $\mathrm{R}_{\mathrm{F}}$ 0.7. The band was washed from the silica gel with $\mathrm{CH}_{2} \mathrm{Cl}_{2}$ and crystallized by diffusion of hexane into a $\mathrm{CH}_{2} \mathrm{Cl}_{2}$ solution of the compound affording very small dark red-orange plates of the title compound $\mathbf{8}, 7.7 \mathrm{mg}, 8.1 \mu \mathrm{mol}, 0.65 \%$. IR(ATR): $v_{\max } / \mathrm{cm}^{-1} v \mathrm{C}=\mathrm{O} 1760 ; v \mathrm{~B}-\mathrm{H}$ 2503. $\mathrm{m} / \mathrm{z}(\mathrm{FAB}$, exact mass spectra were collected on a JEOL JMS700 mass spectrometer in the FAB mode with an NBA matrix together with ca. $0.1 \mathrm{mmol}$ of CsI co-solute): $\mathrm{C}_{28} \mathrm{H}_{51} \mathrm{~B}_{7} \mathrm{O}_{1} \mathrm{P}_{4} \mathrm{~S}_{1} \mathrm{Rh}_{1} \mathrm{Ir}_{1} \mathrm{Cs},[\mathrm{M}+\mathrm{Cs}]^{+}$, meas. 1085.1259, calc. 1085.1268.

The ${ }^{11} \mathrm{~B}-\left\{{ }^{1} \mathrm{H}\right\}$ NMR spectrum showed a mixed envelope between +5 and -10 ppm comprising sharp and underlying broad resonances with a total integrated intensity of 8 boron atoms plus one sharp resonance at higher field. Of these, the following may be individually identified: $\delta\left({ }^{11} \mathrm{~B}\right)\left[\delta\left({ }^{1} \mathrm{H}\right)\right.$ in brackets] $\left(\mathrm{CD}_{2} \mathrm{Cl}_{2}, 293 \mathrm{~K}\right), 2 \mathrm{BH}+5.6[+5.30,+0.07], 1 \mathrm{BH}+2.9[+3.22], 1 \mathrm{BH}-0.4[+3.98], 1 \mathrm{BH}-$ $2.0[+3.00], 3 \mathrm{BH}-10.4[+2.48]$ together with $1 \mathrm{BH}-37.0[+1.47] .{ }^{1} \mathrm{H}-\left\{{ }^{11} \mathrm{~B}\right\} \mathrm{NMR}(300 \mathrm{MHz}$; $\mathrm{CD}_{2} \mathrm{Cl}_{2} ; 298 \mathrm{~K}$ ): $\delta 7.3$ to 7.9 (aromatic region), $+1.58\left[\mathrm{~d},{ }^{2} J\left({ }^{31} \mathrm{P}-{ }^{1} \mathrm{H}\right)=9 \mathrm{~Hz}, \mathrm{Ir}-\mathrm{PMe} e_{3}\right]+1.50\left[\mathrm{~d},{ }^{2} J\right.$ $\left.\left({ }^{31} \mathrm{P}-{ }^{1} \mathrm{H}\right)=10 \mathrm{~Hz}, \mathrm{Ir}-\mathrm{PMe} e_{3}\right],+0.90\left[\mathrm{~d},{ }^{2} J\left({ }^{31} \mathrm{P}-{ }^{1} \mathrm{H}\right)=9 \mathrm{~Hz}, \mathrm{Rh}-\mathrm{PMe} e_{3}\right] \cdot{ }^{31} \mathrm{P}-\left\{{ }^{1} \mathrm{H}\right\}$ NMR $(161 \mathrm{MHz} ;$ $\left.\mathrm{CDCl}_{3} ; 243 \mathrm{~K}\right): \delta+43.6\left[\mathrm{~d},{ }^{1} J\left({ }^{103} \mathrm{Rh}-{ }^{31} \mathrm{P}\right)=189 \mathrm{~Hz},{ }^{2} J\left({ }^{31} \mathrm{P}(4)-{ }^{31} \mathrm{P}(3)\right)=44 \mathrm{~Hz}, P(4) \mathrm{Ph}_{3}\right],-28.1[\mathrm{~d}$, 
$\left.P(3) \mathrm{Me}_{3}\right],-27.7\left[\mathrm{~d},{ }^{2} J\left({ }^{31} \mathrm{P}(1)-{ }^{31} \mathrm{P}(2)\right)=25 \mathrm{~Hz}, P \mathrm{Me}_{3}\right],-45.0\left[\mathrm{~d},{ }^{2} J\left({ }^{31} \mathrm{P}(1)-{ }^{31} \mathrm{P}(2)\right)=25 \mathrm{~Hz}\right.$,

$\left.P \mathrm{Me}_{3}\right]$.

\subsection{X-ray crystallography}

X-ray diffraction data were collected at low temperature (100(2) K) on an automatic Bruker Kappa APEX DUO CCD area detector diffractometer equipped with graphite-monochromated Mo-K $\alpha$ radiation $(\lambda=0.71073 \AA)$ using narrow frames $\left(0.3^{\circ}\right.$ in $\left.\omega\right)$ for 6 ; and on a the BM16 CRG beamline at the ESRF in the case of $\mathbf{5}$ and $\mathbf{8}$. In all cases, single crystals were mounted on micro-mount supports and were covered with a protective perfluoropolyether. The structures were solved and refined using the programmes SADABS and SHELXL-97 respectively $[68,69]$. The programs ORTEP-3 [70] and PLATON [71] were used to prepare Figures 1 and 3. Collection and refinement data are shown in Table 3.

Table 3. Crystallographic and structure refinement data

\begin{tabular}{|c|c|c|c|}
\hline Compound & 5 & 6 & 8 \\
\hline Chemical formula & $\mathrm{C}_{7} \mathrm{H}_{29} \mathrm{~B}_{8} \mathrm{IrOP}_{2} \mathrm{~S}$ & $\mathrm{C}_{37} \mathrm{H}_{41} \mathrm{~B}_{8} \mathrm{OP}_{2} \mathrm{RhS}$ & $\mathrm{C}_{28} \mathrm{H}_{51} \mathrm{~B}_{9} \mathrm{IrOP}_{4} \mathrm{RhS}$ \\
\hline Formula Mass & 501.98 & 785.09 & 952.06 \\
\hline Crystal system & Monoclinic & Monoclinic & Monoclinic \\
\hline$a / \AA ̊ \AA$ & $12.8736(10)$ & $11.0766(5)$ & $12.1060(10)$ \\
\hline$b / \AA$ & $16.7758(13)$ & $21.6858(11)$ & $25.7300(10)$ \\
\hline$c / \AA$ & $26.890(2)$ & $15.3462(8)$ & $12.3430(10)$ \\
\hline$\alpha /^{\circ}$ & 90.00 & 90.00 & 90.00 \\
\hline$\beta /^{\circ}$ & $96.4460(10)$ & $93.0830(10)$ & $95.659(2)$ \\
\hline$\gamma /{ }^{\circ}$ & 90.00 & 90.00 & 90.00 \\
\hline Unit cell volume $/ \AA^{3}$ & $5770.7(8)$ & $3680.9(3)$ & $3826.0(5)$ \\
\hline Temperature/K & $100(2)$ & $100(2)$ & $100(2)$ \\
\hline Space group & $P 21 / c$ & $C c$ & $P 21 / n$ \\
\hline$Z$ & 12 & 4 & 4 \\
\hline Radiation type & $\operatorname{MoK} \alpha$ & MoK $\alpha$ & Synchrotron \\
\hline Absorption coefficient, $\mu / \mathrm{mm}^{-1}$ & 7.202 & 0.639 & 4.391 \\
\hline No. of reflections measured & 40161 & 21879 & 53605 \\
\hline No. of independent reflections & 13259 & 8584 & 8503 \\
\hline$R_{\text {int }}$ & 0.0499 & 0.0172 & 0.0795 \\
\hline Final $R_{l}$ values $(I>2 \sigma(I))$ & 0.0363 & 0.0204 & 0.0433 \\
\hline Final $w R\left(F^{2}\right)$ values $(I>2 \sigma(I))$ & 0.0758 & 0.0532 & 0.1237 \\
\hline Final $R_{l}$ values (all data) & 0.0698 & 0.0207 & 0.0446 \\
\hline Final $w R\left(F^{2}\right)$ values (all data) & 0.0841 & 0.0535 & 0.1256 \\
\hline Goodness of fit on $F^{2}$ & 0.935 & 1.029 & 1.098 \\
\hline
\end{tabular}

\subsection{Calculations}

All calculations were performed using the Gaussian 03 package [72]. Structures were initially optimized using standard methods with the STO-3G* basis-sets for C, B, P, S, and $\mathrm{H}$ with the 
LANL2DZ basis-set for the metal atom. The final optimizations, including frequency analyses to confirm the true minima, together with GIAO nuclear-shielding calculations, were performed using B3LYP methodology, with the 6-31G* and LANL2DZ basis-sets. The GIAO nuclear shielding calculations were performed on the final optimized geometries, and computed ${ }^{11} \mathrm{~B}$ shielding values were related to chemical shifts by comparison with the computed value for $\mathrm{B}_{2} \mathrm{H}_{6}$, which was taken to be $\delta\left({ }^{11} \mathrm{~B}\right)+16.6 \mathrm{ppm}$ relative to the $\mathrm{BF}_{3}\left(\mathrm{OEt}_{2}\right)=0.0 \mathrm{ppm}$ standard. Computed carbonyl frequencies are given with a 0.9613 scaling factor [73].

\section{Acknowledgements}

We acknowledge the Spanish Ministry of Science and Innovation (CTQ2009-10132, CONSOLIDER INGENIO, CSD2009-00050, MULTICAT and CSD2006-0015, Crystallization Factory) and the Grant Agency of the Czech Republic (grant no. P207/11/1577) for support of this work. J.B. thanks the Spanish Ministry of Science Innovation for sabbatical funding (SAB2009-0191) and S.L. thanks the "Ministerio de Ciencia y Tecnología" for a pre-doctoral scholarship.

\section{Appendix. Supplementary material}

X-ray data in CIF format for 5, 6 and 8. DFT-calculated Cartesian coordinates for $\mathbf{6 , 7}$ and $\mathbf{8 .}$

\section{References}

[1] M.A. Fox, Polyhedral Carboranes, in: R.H. Crabtree, D.M.P. Mingos (Eds.) Comprehensive Organometallic Chemistry III, Elsevier Ltd., Oxford, 2007, pp. 49-112.

[2] T. Onak, Polyhedral Organoboranes, in: G. Wilkinson, F.G.A. Stone, E.W. Abel (Eds.) Comprehensive Organometallic Chemistry, Pergamon Press, Ltd., Oxford, 1982, pp. 411-457.

[3] T. Onak, Polyhedral Carboranes, in: E.W. Abel, F.G.A. Stone, G. Wilkinson (Eds.)

Comprehensive Organometallic Chemistry, Elsevier Science Ltd., Oxford, 1995, pp. 217-255.

[4] R.N. Grimes, Metallacarboranes and Metallaboranes, in: G. Wilkinson, F.G.A. Stone, E.W. Abel (Eds.) Comprehensive Organometallic Chemistry, Pergamon Press Ltd., Oxford, 1982, pp. 459-542. 
[5] R.N. Grimes, Transition Metal Metallacarboranes, in: E.W. Abel, F.G.A. Stone, G. Wilkinson

(Eds.) Comprehensive Organometallic Chemistry II, Pergamon, Oxford, 1995, pp. 373-430.

[6] N.S. Hosmane, J.A. Maguire, Metallacarboranes of d- and f-Block Metals, in: R.H. Crabtree, D.M.P. Mingos (Eds.) Comprehensive Organometallic Chemistry, Elsevier, Oxford, 2007, pp. 175264.

[7] Z. Xie, Coord. Chem. Rev., 231 (2002) 23-46.

[8] Z. Xie, Acct. Chem. Res., 36 (2003) 1-9.

[9] Z. Qiu, S. Ren, Z. Xie, Acct. Chem. Res., 44 (2011) 299-309.

[10] J. Zhang, Z. Xie, Chem.-Asian J., 5 (2010) 1742-1757.

[11] R. Satapathy, B.P. Dash, J.A. Maguire, N.S. Hosmane, Collect. Czech. Chem. Commun., 75 (2010) 995-1022.

[12] X.-L. Meng, Qufu Shifan Daxue Xuebao, Ziran Kexueban, 36 (2010) 101-104.

[13] A.R. Kudinov, D.A. Loginov, Russ. Chem. Bull., 58 (2010) 600-603.

[14] W. Kaim, N.S. Hosmane, J. Chem. Sci. (Bangalore, India), 122 (2010) 7-18.

[15] N.S. Hosmane, Y. Zhu, J.A. Maguire, W. Kaim, M. Takagaki, J. Organomet. Chem., 694 (2009) 1690-1697.

[16] P.A. Jelliss, Inorg. Chem., 29 (2008) 1-25.

[17] L.T. Todd, Heterocarboranes, in: G. Wilkinson, F.G.A. Stone, E.W. Abel (Eds.) Comprehensive Organometallic Chemistry, Pergamon Press Ltd., Oxford, 1982, pp. 534-553.

[18] S. Hermánek, Chem. Rev., 92 (1992) 325.

[19] L.T. Todd, Main-group Heteroboranes, in: E.W. Abel, F.G.A. Stone, G. Wilkinson (Eds.) Comprehensive Organometallic Chemistry II, Elsevier Science, Oxford, 1995, pp. 257-273.

[20] L. Wesemann, s- p-Block Heteroboranes and Carboranes, in: D.M.P. Mingos, R.H. Crabtree (Eds.) Comprehensive Organometallic Chemistry, Elsevier, Oxford, 2007, pp. 113-131.

[21] S. Kupper, P.J. Carroll, L.G. Sneddon, J. Am. Chem. Soc., 114 (1992) 4914-4915.

[22] S.O. Kang, L.G. Sneddon, Inorg. Chem., 27 (1988) 3769-3772.

[23] K.J. Donaghy, P.J. Carroll, L.G. Sneddon, Inorg. Chem., 36 (1997) 547-553. 
[24] T. Jelinek, C.A. Kilner, S.A. Barrett, M. Thornton-Pett, J.D. Kennedy, Chem. Commun., (1999) 1905-1906.

[25] T. Jelinek, J.D. Kennedy, B. Stibr, M. Thorntonpett, Angew. Chem. Int. Ed., 33 (1994) 15991601.

[26] M. Bown, X.L.R. Fontaine, N.N. Greenwood, J.D. Kennedy, Z. Anorg. Allg. Chem., 602 (1991) 17-29.

[27] R.W. Rudolph, W.R. Pretzer, Inorg. Synth., 22 (1983) 226-231.

[28] K. Baše, M.G.H. Wallbridge, X.L.R. Fontaine, N.N. Greenwood, J.H. Jones, J.D. Kennedy, B. Stibr, Polyhedron, 8 (1989) 2089-2090.

[29] B. Calvo, M. Kess, R. Macias, C. Cunchillos, F.J. Lahoz, J.D. Kennedy, L.A. Oro, Dalton. Trans., 40 (2011) 6555-6564.

[30] A. Alvarez, R. Macias, M.J. Fabra, F.J. Lahoz, L.A. Oro, J. Am. Chem. Soc., 130 (2008) 21482149.

[31] A. Alvarez, R. Macias, J. Bould, M.J. Fabra, F.J. Lahoz, L.A. Oro, J. Am. Chem. Soc., 130 (2008) 11455-11466.

[32] A. Alvarez, R. Macias, J. Bould, C. Cunchillos, F.J. Lahoz, L.A. Oro, Chem. Eur. J., 15 (2009) 5428-5431.

[33] J.I. van der Vlugt, J.N. Reek, Angew. Chem. Int., 48 (2009) 8832-8846.

[34] B. Calvo, R. Macías, C. Cunchillos, F.J. Lahoz, L.A. Oro, Organometallics, (2011), DOI: $10.1021 / \mathrm{om} 200707 \mathrm{~m}$.

[35] C. Elschenbroich, Organometallics, Wiley-VCH, Weinheim, 2006.

[36] T.P. Fehlner (Ed.), Inorganometallic Chemistry, Plenum Press, New York, 1992.

[37] G.D. Friesen, A. Barriola, P. Daluga, P. Ragatz, J.C. Huffman, L.J. Todd, Inorg. Chem., 19 (1980) 458.

[38] G. Ferguson, M.F. Hawthorne, B.a. Kaitner, F.J. Lalor, Acta Cryst., C40 (1984) 1707.

[39] K. Nestor, X.L.R. Fontaine, N.N. Greenwood, J.D. Kennedy, M. Thornton-Pett, J. Chem. Soc., Dalton Trans., (1991) 2657, 2667. 
[40] K.J. Adams, T.D. McGrath, R.L. Thomas, A.S. Weller, A.J. Welch, J. Organomet. Chem., 527 (1997) 283-285.

[41] K.J. Adams, T.D. McGrath, G.M. Rosair, A.S. Weller, A.J. Welch, J. Organomet. Chem., 550 (1998) 315-329.

[42] G. Ferguson, M.C. Jennings, A.J. Lough, S. Coughlan, T.R. Spalding, J.D. Kennedy, X.L.R. Fontaine, B. Stibr, J. Chem. Soc., Chem. Commun., (1990) 891-894.

[43] S. Coughlan, T.R. Spalding, G. Ferguson, J.F. Gallagher, A.J. Lough, X.L.R. Fontaine, J.D. Kennedy, B. Stibr, J. Chem. Soc., Dalton Trans., (1992) 2865-2871.

[44] J. Bould, W. Clegg, S.J. Teat, L. Barton, N.P. Rath, M. Thornton-Pett, J.D. Kennedy, Inorg. Chim. Acta, 289 (1999) 95-124.

[45] J. Bould, P. Brint, J.D. Kennedy, M. Thornton-Pett, L. Barton, N.P. Rath, Collect. Czech. Chem. Commun., 62 (1997) 1239-1253.

[46] J. Bould, M. Bown, R.J. Coldicott, E.J. Ditzel, N.N. Greenwood, I. Macpherson, P. MacKinnon, M. Thornton-Pett, J.D. Kennedy, J. Organomet. Chem., 690 (2005) 2701-2720.

[47] M.G.S. Londesborough, C. O'Dowd, J. Bould, S.A. Barrett, C.A. Kilner, M. Thornton-Pett, J.D. Kennedy, J. Chem. Cryst., 30 (2000) 283-289.

[48] Y.-H. Kim, A. Brownless, P.A. Cooke, J.D. Kennedy, M. Thornton-Pett, Inorg. Chem. Commun., 1 (1998) 19-22.

[49] T.K. Hilty, D.A. Thompson, W.M. Butler, R.W. Rudolph, Inorg. Chem., 18 (1979) 2642-2651.

[50] K. Wade, Adv. Inorg. Chem. Radiochem., 18 (1976) 1-66.

[51] R.E. Williams, Adv. Inorg. Chem. Radiochem., 18 (1976) 67-142.

[52] D.E. Hyatt, F.R. Scholer, L.J. Todd, Inorg. Chem., 6 (1967) 630-631.

[53] W.N. Lipscomb, R.J. Wiersema, M.F. Hawthorne, Inorg. Chem., 11 (1972) 651-652.

[54] R.R. Rietz, A.R. Siedle, R.O. Schaeffer, L.J. Todd, Inorg. Chem., 12 (1973) 2100-2102.

[55] M. Bown, X.L.R. Fontaine, J.D. Kennedy, J. Chem. Soc., Dalton Trans., (1988) 1467-1473.

[56] R. Macías, J. Bould, J. Holub, J.D. Kennedy, B. Štibr, M. Thornton-Pett, Dalton. Trans., (2007) $2885-2897$. 
[57] J. Bould, T. Base, M.G.S. Londesborough, L.A. Oro, R. Macias, J.D. Kennedy, P. Kubat, M.

Fuciman, T. Polivka, K. Lang, Inorg. Chem., 50 (2011) 7511-7523.

[58] S.O. Kang, P.J. Carroll, L.G. Sneddon, Inorg. Chem., 28 (1989) 961.

[59] K. Nestor, X.L.R. Fontaine, N.N. Greenwood, J.D. Kennedy, M. Thornton-Pett, J. Chem. Soc., Dalton Trans., (1991) 2657-2667.

[60] K.J. Adams, T.D. McGrath, A.J. Welch, Polyhedron, 17 (1998) 341, 349.

[61] O. Volkov, N.P. Rath, L. Barton, Organometallics, 22 (2003) 2548-2550.

[62] J. Bould, C. Cunchillos, F.J. Lahoz, L.A. Oro, J.D. Kennedy, R. Macías, Inorg. Chem., 49 (2010) 7353-7361.

[63] J. Bould, J.D. Kennedy, Chem. Commun., (2008) 2447-2449.

[64] J. Bould, C.A. Kilner, J.D. Kennedy, Dalton. Trans., (2005) 1574-1582.

[65] D. Evans, J.A. Osborn, G. Wilkinson, Inorg. Synth., 11 (1968) 99-101.

[66] K. Vrieze, J.P. Collman, C.T. Sears Jr., M. Kubota, Inorg. Synth., 11 (1968) 101-104.

[67] J.A. Labinger, J.A. Osborn, Inorg. Synth., 18 (1983) 62-65.

[68] G.M. Sheldrick, in, SADABS Program for Correction of Area Detector Data, Univerisity of Göttingen, Göttingen, Germany, 1999.

[69] G.M. Sheldrick, in, SHELXL-97, University of Göttingen: Göttingen, Germany, 1997.

[70] L.J. Farrugia, J. Appl. Cryst., 32 (1999) 837-838.

[71] A.L. Spek, J. Appl. Cryst., 36 (2003) 7-13.

[72] M.J. Frisch, J.A. Pople, in: GAUSSIAN 03 (Rev. C.02), Gaussian, Inc, Wallingford, CT, 2004.

[73] J.P. Merrick, D. Moran, L. Radom, J. Phys. Chem. A, 111 (2007) 11683-11700. 